\title{
IDE PEMBAHARUAN NAPOLEON BONAPARTE DAN AL- TAHṬ̂̄WĪ DI MESIR
}

\author{
Nuruddin* \\ *Dosen Jurusan Bahasa dan Sastra Arab UNJ \\ Kampus A, UNJ Jl. Rawamangun Muka Jakarta 13220 \\ Email: zahanuruddin@yahoo.com
}

\begin{abstract}
ملخص
ويهدف هذا البحث إلى كشف عن الأفكار المجددة عبرها نابليون بونابرت و الطهطاوي في مصر ، ويستخدم هذا البحث الدراسة المكتبية ، وهي الكشف عن مثل البحث أدبيات ذات الصلة بالموضوع ، وقراءتها و تحليلها لمعرفة الأفكار المجددة التي رأاها نابليون بونابرت والطهطاوي في مصر • وخلص هذا البحث إلى أن الأفكار المجددة التي يقوم بها نابليون بونابرت في مصر هي: ( 1 ) فكرة نظام الحكومة الجمههورياة ، ( 2 ) فكرة المساواة ، ( 3 ) و الفكرة الجنسية. و الأفكار المجددة التي قام الطهطاوي في مصر هي: ( 1 ) إدارة الدولة ، (2 ) و التعليم ، ( 3 ) و الوطنية. كلمات البحث: فكرة والتجديد ، نابليون بونابرت ، رفاعاة الطهطاوي
\end{abstract}

\begin{abstract}
ABSTRAK
Penelitian ini bertujuan mengungkapkan ide-ide pembaharuan yang dilakukan Napoleon Bonaparte dan Al-Tahtāwi di Mesir. Penelitian ini menggunakan studi pustaka, berupa menelusuri literatur-literatur yang terkait dengan tema, membaca dan menganalisis untuk menentukan ide-ide pembaharuan yang dilakukan Napoleon Bonaparte dan Al-Tahtāwi di Mesir. Penelitian ini menyimpulkan bahwa ide-ide pembaharuan yang dilakukan oleh Napoleon Bonaparte di Mesir adalah: (1) ide sistem pemerintahan republik, (2) ide persamaan, dan (3) ide kebangsaan. Sedangkan ide-ide pembaharuan yang dilakukan oleh Al-Tahtāwi di Mesir adalah: (1) ketatanegaraan, (2) pendidikan, dan (3) patriotisme.
\end{abstract}

Kata Kunci: Ide, pembaharuan, Napoleon Bonaparte, Al-Tahtāwi. 


\section{PENDAHULUAN}

Menjelang abad 19 bangsa-bangsa yang mendiami kawasan yang sekarang disebut Timur Tengah itu (yaitu negaranegara Arab, termasuk Mesir) tampaknya sedang 'tidur nyenyak'. Mereka dalam kondisi yang memprihatinkan dan sangat lemah, baik dalam arti politik, ekonomi maupun kebudayaan.

Kondisi tersebut diilustrasikan oleh seorang filosof Perancis yang pernah singgah di Mesir dan negara-negara Arab lain dengan ungkapan: "Kebodohan merupakan fenomena umum di Mesir dan negara-negara kekuasaan Turki. Fenomena itu terjadi di segala lapisan dan segala bidang....Bahkan keterampilan tanganpun mereka lakukan dengan sangat sederhana. Sampai-sampa mereparasi jam tangan mereka tidak mampu, sehingga pekerjaan ini dilakukan oleh orang asing" (Jūdat al-Rikābī, 1982: 251).

Bahkan al-Jabarti sendiri-seorang sejarawan Mesir-mengungkapkan keprihatinan yang mendalam tentang gambaran masyarakat Mesir saat itu; "Takkala ilmuan-ilmuan Perancis melakukan eksperimen-eksperimen kimiawi, orangorang Mesir takjub dan berkomentar bahwa yang mereka lakukan adalah praktik sihir" (Jūdat al-Rikābī, 1982: 251).

Dalam kondisi seperti inilah Napoleon datang ke Mesir pada tahun 1879 M. Pendudukan Napoleon ini dapat dikatakan sebagai awal terjadinya kontak bangsa Arab dengan dunia luar (baca: Barat). Dan oleh sejarawan peristiwa itu dijadikan sebagai titik tolak lahirnya Renaissance di dunia Arab.

\begin{tabular}{|c|c|}
\hline Bagaimana & jelasnya \\
\hline dilakukan oleh & Napoleon, \\
\hline
\end{tabular}
ditransformasikan kepada bangsa Mesir dan sejauh mana elit-elit politik dan tokoh-tokoh Mesir, seperti Al-Tahtāî̄i merespon ide-ide pembaharuan yang telah dibentangkan oleh Napoleon, untuk itu makalah ini ditulis.

\section{Napoleon Bonaparte (1769-1821 M)}

Ia dilahirkan pada tanggal 15 Agustus

1769 di Ajaccio, wilayah Corsica, dengan nama babtis Napoleone Bounaparte. Namun setelah menikah ia lebih terkenal dengan Napoleon Bonaparte. Ayahnya-Carlo Bonaportae-adalah seorang pengacara ternama. Sedangkan ibunya Letizia Ramolino, seorang bangsawan dan putri Perencis I dari Austria (Ensiklopedi Nasional, tt: 2334).

Tidak lama setelah masuk sekolah militer, pada tahun 1784 Napoleon dikirim untuk mendalami militer dengan spesialisasi altileri di sekolah militer di Paris yang merupakan sekolah unggulan tempat sekolah anak-anak kaum bangsawan dan tempat melahirkan jenderal-jenderal masa depan. Setahun kemudian ia lulus dengan pangkat pembantu letnan pada usia 16 tahun (A.W. Palmer, 1798: 230).

Pada tahun 1791 atas bantuan kakanya Joseph yang telah menjadi seorang politikus, Napoleon dapat bertugas di Corsica dengan pangkat letnan kolonel. Sejak itu karirnya terus menanjak, dan setelah memenangkan pertempuran melawan Inggris di kota Toulon pada tahun 1793, Napoleon diberi pangkat Brigadir Jenderal pada usia 24 tahun. Dua tahun kemudian setelah mematahkan pemberontakan kaum royalis di Paris, ia naik pangkat menjadi Mayor Jenderal. Dan menjadi Jenderal Besar pada usia 27 tahun, yaitu setelah memenangkan pertempuran di Lodi tahun 1796 dan Rivoli tahun 1797 (A.W. Palmer, 1798: 230 dan Marwati Djoenet Pusponegoro, 1982: 175).

Pada tahun 1798 ia mengadakan

ekspedisi ke Mesir, setahun kemudian ia meninggalkan Mesir kembali ke Perancis. Di sana ia membentuk pemerintahan konsul dan terpilih menjadi konsul yang pertama. Pada tahun 1804 Napoleon memahkotai dirinya dihadapan Paus di Katedral Notre Dame Paris (The Encylopedia Americana, tt: 731). Sejak tahun tersebut sampai tahun 1814 Napoleon menjadi penguasa Perancis yang diktator.

Pada tahun 1815 kekuasaan Napoleon berakhir dengan kekalahannya pada pertempuran di Waterloo. Ia kemudian diasingkan ke Saint Helena dan meninggal di sana pada tanggal 5 Mei 1821 karena penyakit kanker perut. Kerangkanya dibawa 
ke Paris dan dimakamkan kembali di bawah lembah Eglise du Dome pada tahun 1840 (Ensiklopedi Nasional, tt: 2334).

\section{Ekspedisi Napoleon ke Mesir}

Napoleon mendarat di Alexandria Mesir pada tanggal 2 Juni 1978 dan keesokan harinya kota pelabuhan yang penting ini jatuh (Syauqī Daif, 1961: 12). Sembilan hari kemudian, Rasyid, suatu kota yang terletak di sebelah Timur Alexandria jatuh pula. Pada tanggal 21 Juli tentara Napoleon sampai di daerah Piramid dekat Kairo. Pertempuran terjadi di tempat itu dan kaum mamluk karena tak sanggup melawan senjata-senjata meriam Napoleon, lari ke Kairo. Tetapi di sana tidak mendapat simpati dari masyarakat Mesir. Akhirnya terpaksa lari ke daerah Mesir sebelah selatan. Pada tanggal 22 Juli, tidak sampai tiga minggu setelah mendarat di Alexandria, Napoleon telah dapat menguasai Mesir (Harun Nasution, 1992: 29).

Di samping itu kedatangan Napoleon ke Mesir yang menjadi tonggak awal kesadaran bangsa Arab, tidak hanya membawa tentara, dalam rombongannya terdapat 500 kaum sipil dan 500 kaum wanita. Di antara kaum sipil itu terdapat 167 ahli berbagai ilmu pengetahuan seperti insinyur, dokter, sejarawan, ahli kimia dan lain-lain, juga membawa mesin cetak untuk mencetak dan menerbitkan media massa (Harun Nasution, 1992: 30).

Penjelasan di atas memberikan pemahaman bahwa, kedatangan Napoleon tidak hanya bertujuan militer saja, melainkan juga untuk keperluan ilmiyah. Hal ini dapat dibuktikan dengan adanya lembaga-lembaga ilmiyah yang dibentuk oleh Napoleon, seperti Institut d 'Egypte dan dua media yang berbahasa Perancis, yaitu La Decade Egyptienne dan Le courrier d 'Egpyte yang terbit mingguan. Selain itu juga diterbitkan al-Tanbihh sebuah media masa yang berbahasa Arab yang memuat peristiwaperistiwa yang terjadi setiap hari dan beritaberita resmi pemerintah (Jūdat al-Rikābī, 1982: 253).

Institut tersebut banyak dikunjungi oleh masyarakat Mesir terutama para ulamanya. Dari kunjungan ini diharapkan mereka semakin bertambah pengetahuannya tentang Mesir, adat istiadat, bahasa dan agamanya. Di sinilah buat pertama kali terjadi kontak antara Bangsa Mesir dan umat Islam dengan peradaban Eropa yang baru dan asing bagi mereka (Harun Nasution, 1992: 30).

Walaupun ekspedisi Napoleon ke Mesir menyebabkan luka tersendiri di kalangan umat Islam, namun sisi positif dapat diambil dari ide-ide baru yang dibawa Napoleon yang dihasilkan dari revolusi Perancis.

\section{Ide-Ide Pembaharuan Napoleon di Mesir 1. Sistem pemerintahan republik}

Sistem pemerintahan republik yang dikemukakan oleh Napoleon ini mempunyai cirri-ciri sebagai berikut: (a) seorang kepala negara dipilih untuk waktu tertentu, (b) ia harus tunduk kepada undang-undang, dan (c) ia dapat dijatuhkan oleh rakyat yang tercermin dalam parlemen. Hal ini berbeda dengan sistem pemerintahan sebelumnya di Mesir yang berbentuk kerajaan, di mana kekuasaan sang raja sangat absolut. Ia berkuasa selama hidupnya, dan kemudian digantikan oleh anaknya, tidak tunduk kepada konstitusi atau parlemen, karena konstitusi atau parlemen tidak ada dalam sistem kerajaan.

Hanya saja ide yang terkandung dalam kata republik masih sulit ditangkap, sehingga ketika menerjemahkannya ke bahasa Arab juga sulit. Contoh "Republik Perancis" diterjemahkan menjadi al-Jumhūr al-Faransāwi (الجمهور الفرنساوى). Padahal al-Jumhur sebenarnya berarti orang banyak. Jadi yang tertangkap dari kata al-Jumhur adalah republik atau publik, orang banyak. Baru kemudian muncul terjemahan yang lebih tepat yaitu: al-Jumhūriyah (Harun Nasution, 1992: 32).

\section{Ide persamaan}

Ide persamaan dalam arti samanya kedudukan dan keikutsertaan rakyat dalam soal pemerintahan negara mereka. Napoleon mendirikan suatu badan kenegaraan dimana rakyat turut serta bertanggung jawab. Anggota badan kenegaraan ini terdiri dari 
ulama-ulama al-Azhar, pemuka-pemuka dagang dari Kairo dan daerah. Badan ini diberi tugas untuk membuat undang-undang, memelihara ketertiban umum dan menjadi pengantara antara penguasa Perancis dan rakyat Mesir (Harun Nasution, 1992: 32). Ide persamaan yang dikembangkan oleh Napoleon menuntut ikut sertanya semua unsur masyarakat untuk berpartisipasi dalam pemerintahan. Yang berperan dalam setiap aktivitas pemerintahan di Mesir bukan hanya orang Perancis tetapi juga rakyat Mesir sendiri. Dalam badan kenegaraan tersebut Napoleon memilih 10 orang untuk duduk di dalamnya yang sebagian besar anggotanya adalah ulama-ulama Al-Azhar. Adapun ketuanya, setelah melalui proses pemilihan, adalah 'Abdullah al-Syarkawî, yang menjabat pula sebagai Syaikh Al-Azhar (Hasan Ibrahim Hasan, 1989: 352).

\section{Ide kebangsaan}

Ide kebangsaan yang terkandung dalam maklumat Napoleon bahwa orang Perancis merupakan suatu bangsa (Nation) dan bahwa kaum Mamluk adalah orang asing yang datang ke Mesir dari Kaukasus. Jadi walaupun mereka orang Islam tetapi berlainan bangsa dengan orang Mesir. Maklumat itu juga mengandung kata-kata Umat Mesir (الآمة المصرية). Pada waktu itu orang Islam hanya mengenal al-ummah alIslamiyah, dan tiap orang Islam adalah bersaudara tanpa menyadari perbedaan bangsa dan suku bangsa. Yang disadarinya adalah perbedaan agama. Oleh karena itu untuk menerjemahkan kata nation ke dalam bahasa Arab merupakan hal yang sulit (Harun Nasution, 1992: 32).

Demikianlah beberapa ide pembaharuan yang dibawa Napoleon ke Mesir. Walaupun ide-ide tersebut belum nyata pengaruhnya bagi bangsa Arab secara umum, namun setelah kontak dengan Barat semakin intens, yaitu mulai abad 19 dan seterusnya ide-ide tersebut mulai menggema yang pada akhirnya dipraktekkan oleh Bangsa Arab sendiri. Tokoh penting Bangsa Arab yang pertama merespon ide-ide pembaharuan yang telah ditabuh oleh Napoleon adalah Al- Tahtāwī.

\section{Al-Tahtāwī}

Nama lengkap Al-Tahtāwī adalah Rifa'ah Badawi Rafi' Al-Tahtāwī lahir pada tahun 1801 di Tahta, suatu kota kecil di Mesir bagian selatan dan meninggal tahun 1873 di Kairo. Ia merupakan murid kesayangan gurunya al-Syekh Hasan al'Attar yang banyak mempunyai hubungan dengan ahli-ahli ilmu pengetahuan Perancis yang datang bersama Napoleon ke Mesir (Harun Nasution, 1992: 42).

Al-Tahtāwī merupakan seorang ulama lulusan Al-Azhar yang menaruh perhatian yang besar pada ilmu pengetahuan yang sedang berkembang di Barat. Di Paris (Perancis) di samping menjalankan tugas sebagai imam, ia dengan usaha dan biaya sendiri mempelajari Bahasa Perancis, dan setelah menguasainya ia mempelajari berbagai ilmu pengetahuan Barat (Harun Nasution, 1996: 139).

Hal itulah yang menyebabkan AlTahtāwī sekembalinya di Mesir ia menjadi salah satu pemikir pembaharuan yang berpengaruh di negeri ini. Di samping menerjemahkan, ia juga mengarang bukubuku yang berisi pemikiran-pemikiran modern. Satu dari sekian banyak buku karangannya adalah "Takhlīs al-Ibrīz fi Takhlīs Bārīz" (Intisari dari kesimpulan tentang Paris) berisi tentang kesan-kesan AlTahtāwī selama perjalanannya ke Paris, yaitu menerangkan hal-hal yang bersangkutan dengan hidup dan kemajuan Eropa, seperti sistem pemerintahannya, revolusi Perancis 1789, konstitusi Perancis, adat istiadat Eropa, cara pemeliharaan kesehatan dan lain-lain.

\section{Usaha-Usaha Pembaharuan Al-Tahtāwī}

Setelah mendapat pengetahuan modern selama ia belajar di Mesir, AlTahtāwī mensosialisasikannya di Mesir tatkala ia menempati posisi yang berpengaruh di Mesir di bawah kekuasaan Muhammad Ali, yaitu tatkala ia menjadi pimpinan majalah al-Waqāiq al-Miśriyah dan Raudah al-Madāris. Ide-ide 
pembaharuan yang sosialisasikan antara lain bidang:

\section{a. Ketatanegaraan}

Di samping membahas sistem ekonomi negara maju buku "Manāhij alAlbāb al-Miśriyah fi Manāhij al-Ādāb al'Assriyah "salah satu buku karangan AlTahtāiwi, juga menerangkan sistem ketatanegaraan negara modern. Raja dan sultan umpamanya, sudah tidak mempunyai kekuasaan mutlak, mereka sudah dibatasi oleh syari'ah dan syura yang dijalankan ulama. Lembaga baru ini berposisi di atas raja, maka raja harus menghormati ulama karena menjadi mitra dalam menjalankan roda pemerintahan. Syari'ah tersebut harus disesuaikan dengan kondisi dan situasi negera modern, dan ulamanya harus mengetahui perkembangan negara-negara, untuk dijadikan landasan di dalam membuat syari'ah yang akan diberlakukan di negara Mesir.

Sebagai contoh, ia menjelaskan bahwa masyarakat suatu negara tersusun empat kelompok, raja beserta stafnya, kaum ulama dan cendekia, merupakan golongan yang menjalankan pemerintahan; tentara, dan produsen merupakan kelompok masyarakat yang harus patuh dan setia kepada pemerintah.

Pola ketatanegaraan yang dikembangkan oleh Al-Tahtāwī di atas mendapat tanggapan positif oleh Albert Hourani, seorang alumni Oxford University yang banyak menulis tentang pemikiran Islam dan bangsa Arab (Albert Hourani dalam Bassan Tibbi, 1994: 132-133). Albert Hourani mengatakan:
"Gagasan-gagasan
Al- Tahtāwī
tentang masyarakat dan negara bukanlah penyataan kembali sebuah pandangan tradisional maupun refleksi sederhana yang ia pelajari di Paris. Format awal yang ia rumuskan mengacu kepada keteladanan Nabi dan para sahabatnya, dan pemikirannya tentang kekuasaan dan politik masih dalam bingkai tradisi Islam, tetapi ia memberikan

perkembangan baru yang ia dapat dari negara modern semisal Perancis"

\section{b. Pendidikan}

Konsep pendidikan yang dikembangkan oleh Al-Tahtāīī terangkup dalam salah satu bukunya yang bernama "AlMursyid al-Amīn li al-Banāt wa al-Banīn”. Pendidikan katanya, disamping harus berkualitas juga harus universal dan sama bentuknya untuk semua golongan, baik lakilaki maupun perempuan. Adapun pendapat umum yang lama tumbuh di masyarakat bahwa menyekolahkan anak perempuan makruh, dibantah dengan kenyataan historis bahwa istri nabi Hafsah merupakan seorang wanita yang pandai membaca dan menulis. Pendidikan yang dikembangkan oleh alTahtawi pada ujungnya melahirkan emansipasi di kalangan wanita, jalan sebelum muncul ide emansipasi wanita Qasim Amin.

\section{c. Patriotisme (Hubbul Wathan)}

Al-Tahtāwīlah yang pertama menganjurkan patriotisme, yang dipahami sebagai dasar yang kuat untuk mendorong orang mendirikan masyarakat yang berperadaban. Faham bahwa seluruh dunia Islam adalah tanah air tiap orang Muslim, telah berubah tekanannya. Tanah air sekarang ditekankan artinya pada tanah tumpah darah seseorang dan bukan seluruh dunia Islam. Jadi harus dipisahkan persaudaraan Islam dan persaudaraan setanah air, dan yang terakhir itulah yang lebih kuat. Seorang warga negara harus menjalin persatuan, tunduk kepada undang-undang dan sedia mengorbankan harta dan raga untuk kepentingan bangsanya.

\section{SIMPULAN}

Ekspedisi yang dilancarkan Napoleon ke Mesir, dalam banyak hal ternyata menimbulkan dampak positif di dunia Arab. Tidak hanya bangsa Mesir saja yang bangkit dari ketertinggalannya, melainkan hampir seluruh negara di kawasan yang yang sekarang disebut Timur Tengah. Nilai positif yang dibawa Napoleon adalah ide-ide pembaharuan, yang dikemudian hari mampu diterjemahkan oleh para elit dan cendikiawan Mesir. Al-Tahtāiwī dapat disebut mewakili 
kelompok cendikiawan yang pertama mengembangkan ide-ide pembaharuan Napoleon, semisal dalam bidang ketatanegaraan, pendidikan, dan patriotisme. Dan perlu dicatat disini bahwa ide-ide pembaharuan tersebut secara umum berkiblat ke negara-negara Eropa, diantaranya Perancis.

\section{DAFTAR PUSTAKA}

A.W. Palmer, A Dictionary of Modern History, 1789.

Bassan Tibbi, Krisis Peradaban Islam Modern, tt: Yogub Tiara, 1994.

Ensiklopedi Nasional, jilid IV

Harun Nasution, Pembaharuan dalam Islam: Sejarah Pemikiran dan Gerakan, Jakarta: Bulan Bintang, 1992.
Islam Rasional, Bandung: Mizan, 1996.

Hasan Ibrahim Hassan, Sejarah dan Peradaban Islam, Yogyakarta: Kota Kembang, 1989.

Joenet Poesponegoro, Tokoh dan Peristiwa dalam Sejarah, Jakarta: Erlangga, 1992.

Jūdat al-Rikābī, al-Adab al-'Arabi min alInhidar ila al-Izdihar, Beirut: Dar alFikr, 1982.

Syauqī Daif, al-Adab al- 'Arabi al-Mu'asir fi Misr, Kairo: Dar al-Ma'arif, 1961.

The Encylopedia Americana, jilid XIX, tt. 